\title{
A matrix-assisted laser desorption ionization post-source decay (MALDI-PSD) analysis of proteins released from isolated liver mitochondria treated with recombinant truncated Bid
}

G Van Loo', H Demol', M van Gurp', B Hoorelbeke', P Schotte $^{3}$, R Beyaert ${ }^{3}$, B Zhivotovsky ${ }^{4}$, K Gevaert ${ }^{2}$, W Declercq ${ }^{1}$, J Vandekerckhove ${ }^{2}$ and $P$ Vandenabeele ${ }^{*, 1}$

${ }^{1}$ Flanders Interuniversity Institute for Biotechnology and Ghent University, Department of Molecular Biology, Unit of Molecular Signaling and Cell Death, KL Ledeganckstraat 35, B-9000 Gent, Belgium

2 Flanders Interuniversity Institute for Biotechnology and Ghent University, Department of Medical Protein Research, KL Ledeganckstraat 35, B-9000 Gent, Belgium

${ }^{3}$ Flanders Interuniversity Institute for Biotechnology and Ghent University, Department of Molecular Biology, Unit of Molecular Signal Transduction in Inflammation, KL Ledeganckstraat 35, B-9000 Gent, Belgium

${ }^{4}$ Karolinska Institute, Institute of Environmental Medicine, Unit of Toxicology and Neurotoxicology, Box 210, S-171 77 Stockholm, Sweden

* Corresponding author: P Vandenabeele, Flanders Interuniversity Institute for Biotechnology and Ghent University, Department of Molecular Biology, Unit of Molecular Signaling and Cell Death, KL Ledeganckstraat 35, B-9000 Gent, Belgium. Tel: ++32 9264 5131; Fax: ++32 9264 5348;

E-mail: peter.vandenabeele@dmb.rug.ac.be

Received 1.7.01; revised 18.9.01; accepted 26.9.01

Edited by J-C Martinou

\section{Abstract}

A crucial event in the process of apoptosis is caspasedependent generation of truncated Bid (tBid), inducing release of cytochrome $c$. In an in vitro reconstitution system we combined purified recombinant tBid with isolated liver mitochondria and identified the released proteins using a proteomic matrix-assisted laser desorption ionization postsource decay (MALDI-PSD) approach. In order to meet physiological conditions, the concentration of tBid was chosen such that it was unable to induce cytochrome $c$ release in mitochondria derived from liver-specific $\mathrm{Bcl}-2$-transgenic mice. Several mitochondrial proteins were identified to be released in a tBid-dependent way, among which cytochrome $c$, DIABLO/ Smac, adenylate kinase 2, acyl-CoA-binding protein, endonuclease G, polypyrimidine tract-binding protein, a type-I RNA helicase, a WD-40 repeat-containing protein and the serine protease Omi. Western blotting confirmed the absence of adenylate kinase 3, a matrix mitochondrial protein. These results demonstrate that a physiologically relevant concentration of tBid is sufficient to induce release of particular intermembrane mitochondrial proteins belonging to a broad molecular-mass range.

Cell Death and Differentiation (2002) 9, 301-308. DOI: 10.1038/ $\mathrm{sj} / \mathrm{cdd} / 4400966$

Keywords: apoptosis; caspase; MALDI-PSD; mitochondria; tBid
Abbreviations: $A K$, adenylate kinase; $E R$, endoplasmic reticulum; MALDI, matrix-assisted laser desorption ionization; MS, mass spectrometry; PSD, post-source decay; PTB, polypyrimidine tract binding; tBid, truncated Bid

\section{Introduction}

It has become clear that mitochondria play a central role in the process of cell death. These organelles are targets for proapoptotic and antiapoptotic pathways. Mitochondria participate in the apoptotic process by releasing factors that modulate the activation of caspases. In this respect, release of cytochrome $c$ is required for formation of the Apaf-1/ procaspase- 9 apoptosome complex in the presence of (d)ATP. ${ }^{1,2}$ The recently identified DIABLO/Smac unlatches the inhibitory activity of XIAP on caspase-3, caspase-7 and caspase $-9,{ }^{3-8}$ favoring execution of the apoptotic pathway. Also during necrotic cell death, mitochondria are involved in the production of reactive oxygen species, ${ }^{9}$ but no release of cytochrome $c$ has been observed. ${ }^{10}$

Many different apoptogenic stimuli impinge on the specific proteolysis of Bid, a proapoptotic BH3-only member of the Bcl-2 family. ${ }^{11}$ Bid is proteolytically cleaved by caspase-8, generating $15-\mathrm{kDa}$ truncated Bid (tBid), ${ }^{12,13}$ by granzyme $\mathrm{B}$, leading to $14-\mathrm{kDa} \mathrm{tBid},{ }^{14-16}$ or by lysosomal proteases. ${ }^{17}$ In the prototype CD95 (Fas) apoptotic pathway, ligand binding induces formation of a death-inducing signaling complex, consisting of the Fas-associated death domain protein and procaspase- $8 .{ }^{18}$ The molecular link between these receptor-mediated events and mitochondria is provided by caspase-8-mediated proteolysis of Bid. ${ }^{12,13}$ tBid translocates to the mitochondria and induces cytochrome $c$ release, a process involving the proapoptotic $\mathrm{Bcl}$ 2 members Bax and Bak. ${ }^{19-22}$ Bid-deficient mice are resistant to anti-Fas-induced hepatocyte apoptosis, ${ }^{23}$ which emphasizes the importance of this death domain receptor/ mitochondrial connection. In such hepatocytes, anti-Fasinduced mitochondrial dysfunction is delayed, no cytochrome $c$ is released and activation of downstream effector caspases is reduced. Antiapoptotic $\mathrm{Bcl}-2$ and $\mathrm{Bcl}-\mathrm{X}_{\mathrm{L}}$ proteins do not block cleavage and relocalization of tBid, but can prevent tBid-induced cytochrome $c$ release. ${ }^{24,25}$

Although cytochrome $c$ is the best characterized protein released by mitochondria, other apoptotic proteins translocating to the cytosol of dying cells have been identified and have been shown to influence phenomena associated with apoptosis, such as apoptosis-inducing factor, ${ }^{26}$ DIABLO/ $\mathrm{Smac}^{3,5}$ and some mitochondrial caspases. ${ }^{27,28}$ To address the question whether tBid is able to induce the release of 
such proteins, we used an in vitro reconstitution system in which isolated mouse liver mitochondria were treated with purified recombinant $15-\mathrm{kDa}$ tBid. The tBid concentration used was such that no cytochrome $c$ was released in the mitochondria from Bcl-2-transgenic mice. Subsequently, proteins released in a tBid-dependent way from mitochondria were identified by matrix-assisted laser desorption ionization (MALDI) mass spectrometry (MS).

\section{Results}

To address the question whether tBid is able to induce release of proteins other than cytochrome $c$, we set up a comparative experiment in which isolated liver mitochondria were exposed/unexposed to recombinant 15-kDa tBid. In order to use a relevant concentration of $\mathrm{tBid}$, we determined the amount of tBid at which cytochrome $c$ release is blocked by overexpression of $\mathrm{Bcl}-2$. To that end, mitochondria of a $\mathrm{Bcl}-2$ transgene, placed under control of the hepatocytespecific $\alpha 1$-antitrypsin gene promoter, ${ }^{29}$ were exposed to a serial dilution of recombinant tBid. The release of cytochrome $c$ induced by $6.7 \mathrm{nM}(10 \mathrm{ng} / 100 \mu \mathrm{l})$ of recombinant $\mathrm{tBid}$ was completely abrogated in liver mitochondria from $\mathrm{Bcl}-2$ transgenic mice (Figure 1A). To determine whether the mitochondrial inner membrane was damaged, we checked for the presence of AK2 and AK3. AK2, an intermembrane mitochondrial protein, was shown to be released from mitochondria during the apoptotic process ${ }^{30,31}$ while AK3 is located exclusively in the mitochondrial matrix ${ }^{32}$ and resides there during the process of apoptosis. ${ }^{33}$ As shown in Figure $1 \mathrm{~B}, \mathrm{AK} 2$ was specifically released with tBid, whereas AK3 could not be detected in the mitochondrial supernatant. This suggests that only intermembrane proteins had been released under the conditions used, that the inner mitochondrial membrane had not been damaged and that the matrix had remained intact.

To identify new mitochondrial proteins released with tBid, a large-scale preparation of isolated liver mitochon-

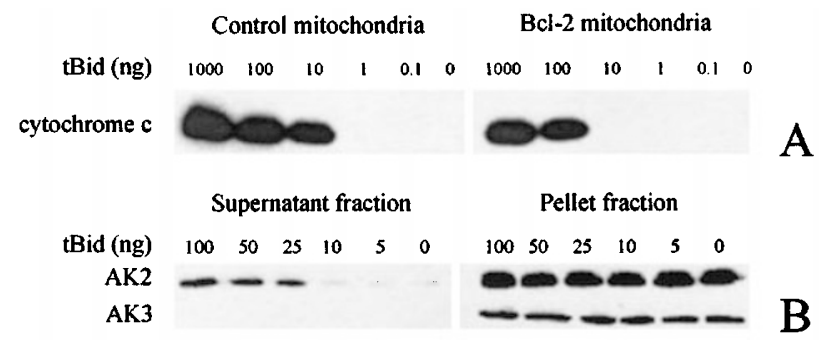

Figure 1 (A) tBid-induced cytochrome $c$ release is blocked in $\mathrm{Bcl}-2$ overexpressing mitochondria. Recombinant tBid was incubated with $40 \mu \mathrm{g}$ protein equivalent of liver mitochondria from control and liver-specific $\mathrm{Bcl}-2$ transgenic mice. Supernatants were separated and subjected to $15 \%$ SDS PAGE, followed by Western blotting using an anti-cytochrome $c$ antibody. Ten $\mathrm{ng}$ of tBid (corresponding to $6.7 \mathrm{nM}$ ) was sufficient to trigger release of cytochrome $c$ in control mitochondria, but no longer in Bcl-2 mitochondria. (B) tBid induces release of AK2, but not of AK3. tBid was incubated with a protein equivalent of $40 \mu \mathrm{g}$ purified mitochondria. Supernatants were separated from the mitochondrial pellets by centrifugation. The supernatant and pellet fractions were subjected to $15 \%$ SDS-PAGE, followed by immunoblotting with anti-AK2 antiserum. The same blots were stripped and analyzed for AK3 presence using an AK3-specific antibody dria was exposed, or not, to recombinant tBid. For purification purposes the resulting supernatant was separated on 15\% SDS-PAGE gels (for low-molecular mass proteins) or $8 \%$ SDS-PAGE gels (for highmolecular mass proteins). Coomassie brilliant blue staining profiles revealed the presence of several tBid-inducible protein bands as compared to untreated controls (Figure 2). Differentially stained protein bands were excised from the gel containing the mitochondrial proteins released by tBid, together with the corresponding bands of the control lane. All excised proteins were in-gel digested using trypsin; a small fraction of the peptide mixture was used for MALDI-MS peptide mass fingerprinting. Since the proteins were separated only by their molecular mass, almost every excised protein band contained multiple proteins, which prevented unambiguous identification by peptide mass maps. Therefore the remainder of the peptide mixture was separated by reverse-phase HPLC, after which fractionated peptides were analyzed by MALDIMS. First, all the peptides present in the protein band excised from the control lane were analyzed and used as a negative control. Next, the peptides from the tBiddependent released protein band were analyzed (Figure $3 A, B)$. Peptides that were solely present in the latter sample or were clearly dominant, were chosen for further sequence analysis by MALDI post-source decay (PSD) (Figure $3 C$ ). As an example, MALDI-PSD analysis of the protein sample identifying the serine protease Omi is shown (Figure 3).

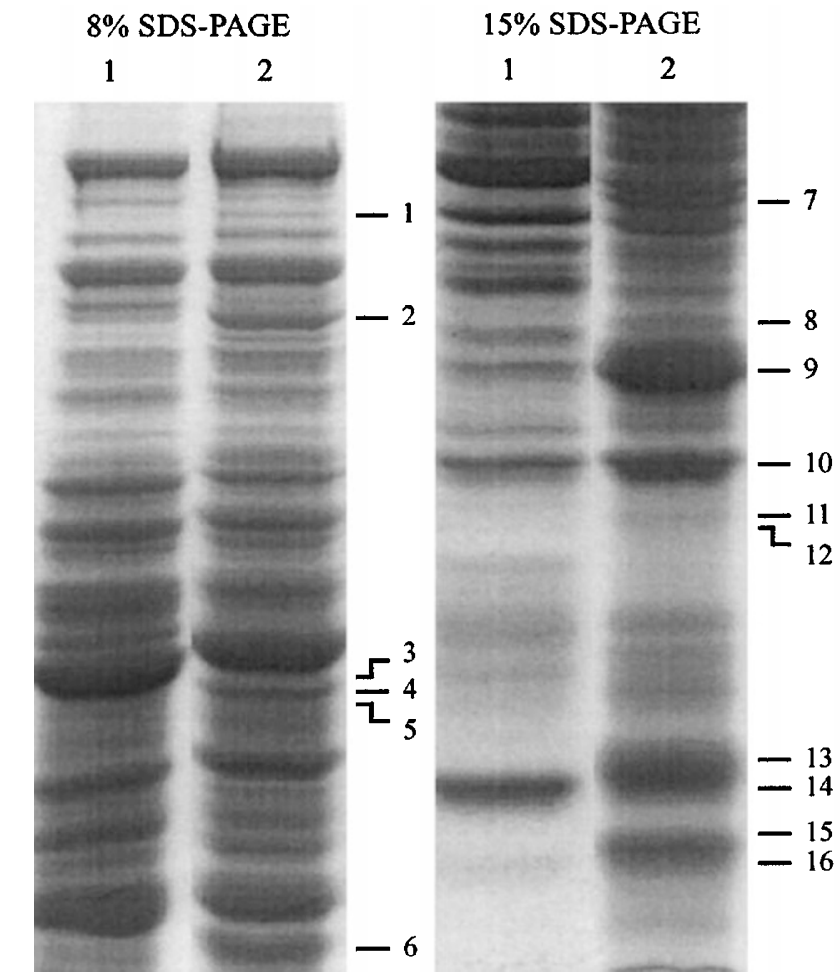

Figure 2 Coomassie brilliant blue staining profiles of tBid-induced mitochondrial supernatants isolated by centrifugation. Differential protein bands (separated by $8 \%$ and $15 \%$ SDS-PAGE) between controls (lanes 1) and tBid-induced supernatants (lanes 2 ) were excised and sequenced 

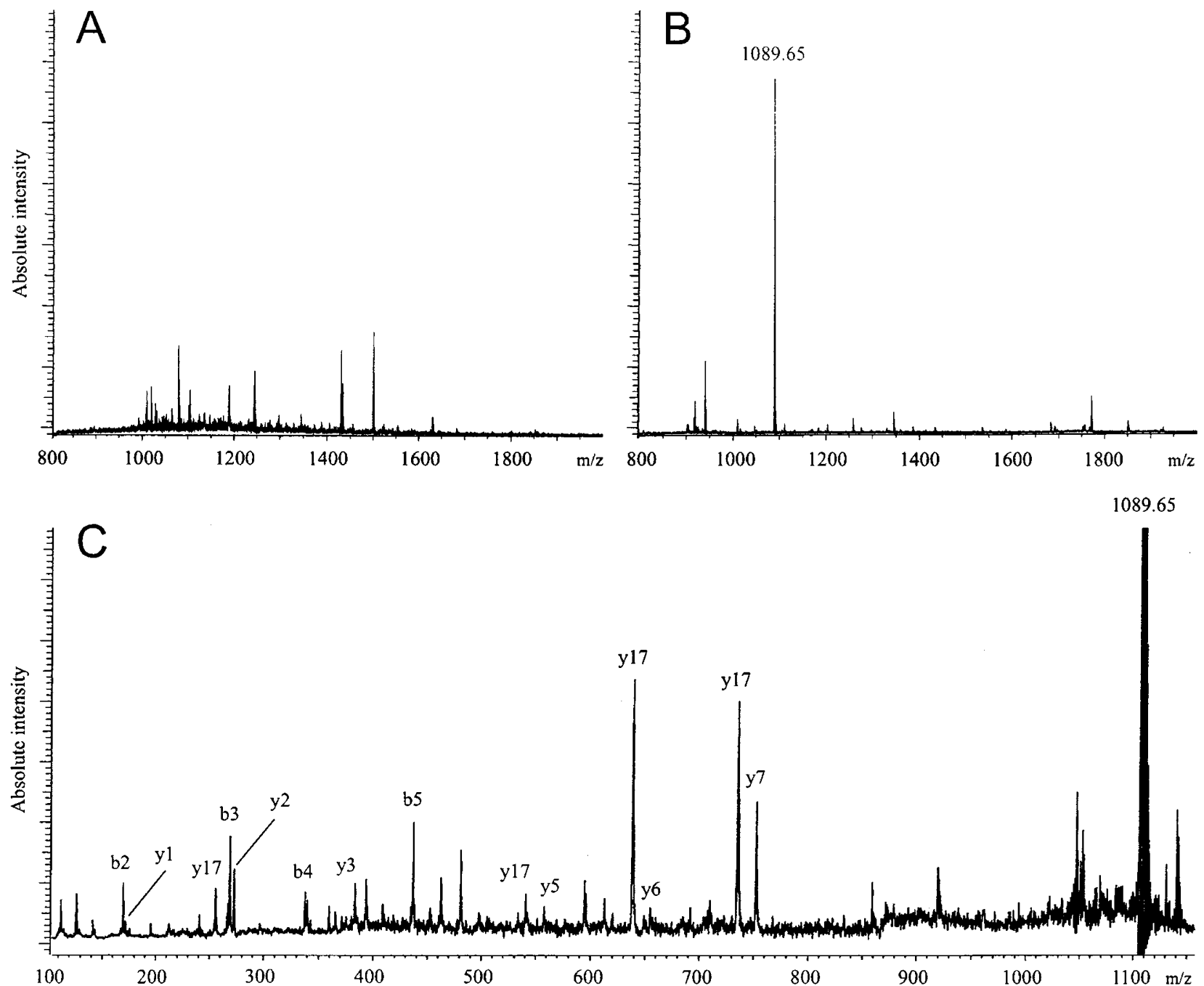

$200 \quad 300$

b5

Figure 3 MALDI-MS identification of the Omi protein released by tBid. Protein band 6 and its control (Figure 2) were digested using trypsin. The peptide mixture generated was separated by reverse phase-HPLC. Shown are MALDI-MS spectra of peptides present in the HPLC fraction from protein digests in negative control (A) and tBid-released (B) proteins. (C) MALDI-PSD analysis of the peptide with a mass of 1089.65 Da present in the spectrum of B permitted to identify the sequence $\mathrm{NH}_{2}$-AVPAPPPTSPR-COOH of the mouse Omi protein. This was further verified by manually checking the PSD spectrum for the presence of other tryptic peptide fragments, cumulatively covering approximately $23 \%$ of the amino acid sequence of the Omi protein (data not shown)

Using this approach, we identified proteins that were released in a recombinant tBid-dependent way and which were not present in the supernatant of untreated mitochondria (Table 1). They include proven apoptogenic proteins such as cytochrome $c$ and DIABLO/Smac. ${ }^{3,5}$ We also detected AK2, a protein without clear function in apoptosis, ${ }^{30,31}$ and a number of proteins from a list of mitochondrial factors released by atractyloside in vitro, such as glutamate dehydrogenase, methylmalonate semialdehyde dehydrogenase, coproporphyrinogen III oxidase, fatty acid-binding protein and acyl-CoA-binding protein. ${ }^{34}$ The functional impact of these proteins on apoptosis is unknown.

Identified was also endonuclease $G$, previously suggested to play a role in mitochondrial DNA replication, ${ }^{35,36}$ and recently found to be released from the mitochondria during apoptosis, where it might be involved in caspase- independent DNA degradation. ${ }^{37-39}$ Endonuclease G seems to be one of the proteins most abundantly released, as can be appreciated from the 15\% Coomassie brilliant blue gel (Table 1 and Figure 2).

Besides these known proteins some new factors were identified: a type-I RNA helicase, polypyrimidine tractbinding protein, the serine protease Omi, a WD-40 repeat-containing protein, actin-related protein $2 / 3$ complex subunit 4 and translocase of inner mitochondrial membrane TIMM13b. Endoplasmin (also called GRP94), the major glycoprotein of the endoplasmic reticulum (ER), was identified as a tBid-released protein, probably due to a minor contamination of the mitochondrial cell fraction with the ER. This observation suggests that tBid has, besides its major activity on mitochondria, an additional effect on the $\mathrm{ER}$, or that endoplasmin has a dual localization in the ER and the mitochondria. 


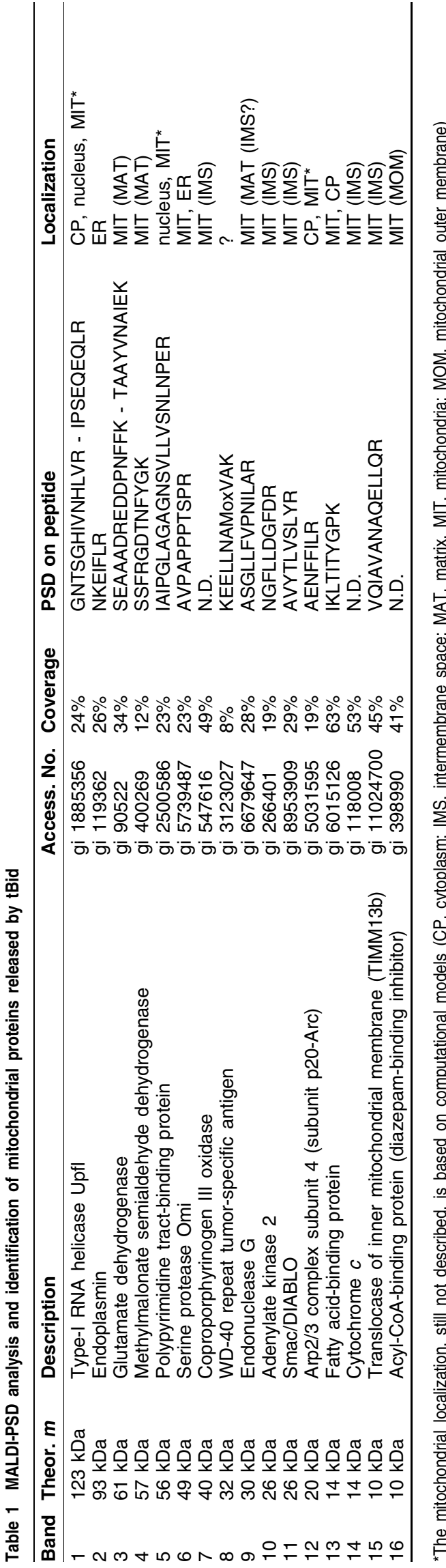

In most cases the difference between tBid-treated and untreated mitochondria led to the identification, in qualitative terms, of extra proteins in the treated condition. However, some protein bands showed a stronger staining in the control sample as compared to the tBid condition (Figure 2). Also in this case, we excised the band of similar height in the lane of tBid-treated mitochondria. The protein identification procedure used in this study is not able to document quantitative differences between protein mixtures. To this end, differential techniques that use stable isotope incorporation into peptides should have been employed. ${ }^{40,41}$ Nevertheless, MALDI-MS analysis of these protein bands did not reveal qualitative differences for these more intensely stained proteins in the case of supernatant from untreated mitochondria. Hence it is possible that a tBid-dependent release of proteases (such as Omi) partially degrades proteins in the mitochondrial supernatant, resulting in a lesser protein content.

\section{Discussion}

Although cytochrome $c$ is the best known and best documented mitochondrial protein released during apoptosis, the mitochondria still contain other apoptogenic factors, such as DIABLO/Smac, ${ }^{3,5}$ apoptosis-inducing factor ${ }^{26,42}$ and mitochondrial caspases. ${ }^{27,28}$ To address the question whether tBid is able to induce the release of such proteins, we set up a comparative experiment in which isolated liver mitochondria were subjected to a relevant concentration of tBid, viz a concentration of tBid at which cytochrome $c$ release is blocked by overexpression of $\mathrm{Bcl}-2$. A proteome analysis was performed on the supernatant of isolated mitochondria (either untreated or treated with recombinant tBid) to determine any tBid-dependent release of proteins. Except for apoptosis-inducing factor and mitochondrial caspases, most mitochondrial proteins already described as being released during apoptosis were identified by our approach. Among the proteins released from the mitochondria during the apoptotic process we identified cytochrome $c$, DIABLO/Smac and $A K 2$, as well as some proteins previously reported to be present in the supernatant of atractyloside-treated isolated mitochondria. The latter include glutamate dehydrogenase, methylmalonate semialdehyde dehydrogenase, coproporphyrinogen III oxidase, fatty acid-binding protein and acylCoA-binding protein. ${ }^{34}$ Glutamate dehydrogenase and coproporphyrinogen III oxidase are implicated in oxidative deamination and heme biosynthesis, respectively. Methylmalonate semialdehyde dehydrogenase is involved in breakdown of branched amino acids. Fatty acid-binding protein binds free fatty acids and may be implicated in intracellular lipid transport. Acyl-CoA-binding protein, the endogenous ligand of the mitochondrial benzodiazepine receptor, is involved in acetyl-CoA ester transport and was reported to cause opening of the permeability transition pore after ligation with its receptor, thus favoring apoptosis. ${ }^{43-45}$ Furthermore, we identified the translocase of the inner mitochondrial membrane TIMM13b, a protein implicated in protein import from the cytoplasm to the mitochondrial inner membrane. Another member of this family, the X-linked deafness-dystonia protein (also called TIMM8a), ${ }^{46}$ has already been described as being 
released from the intermembrane mitochondrial space after treatment with atractyloside. ${ }^{34}$ Also the recently published proapoptotic DNAse endonuclease $\mathrm{G}$, probably involved in caspase-independent DNA degradation, was clearly identified. $^{37-39}$

We also identified a few new proteins released from tBid-treated mitochondria, some of which may modulate apoptotic pathways. An interesting finding is tBid-mediated release of Omi (also named HtrA2), a serine protease homologous to the bacterial heat shock endoprotease HtrA. Omi contains a mitochondrial localization signal ${ }^{47}$ and was suggested to play a role in the degradation of aberrantly folded proteins during cellular stress caused by reactive oxygen species, toxins or ischemia/reperfusion. ${ }^{48,49}$ As tBid induces release of Omi from mitochondria, it is conceivable that its protease activity, once translocated to the cytosol, may regulate apoptotic proteolytic cascades or may proteolyze some substrates implicated in apoptosis. Although caspases, a family of cysteine proteases, are the main players in the apoptotic process, other noncaspase proteases have been described as being involved in apoptosis, including cathepsins, calpains, serine proteases and the proteasome complex..$^{50}$

Another interesting tBid-released protein that may modulate apoptotic pathways, is the polypyrimidine tractbinding (PTB) protein. Little is known about the precise function of this protein, but it was recently recognized as an important player in alternative splicing regulation. ${ }^{51}$ In the context of apoptosis, the PTB protein was shown to bind downstream of the alternative exon 9 of caspase-2, thus preventing inclusion of the alternative exon $9 .^{52}$ Caspase$2 \mathrm{~L}$ is derived from the skipping of alternative exon 9 and can induce cell death in a variety of cells, ${ }^{53,54}$ whereas caspase-2S is a truncated version of the protein due to inclusion of exon 9 (containing a premature termination codon). Since overexpression of caspase-2S prevents apoptotic cell death, ${ }^{53,55}$ release of the PTB protein might favor formation of the proapoptotic caspase-2L form. Most likely, the PTB protein is also involved in the splice regulation of other, possibly apoptosis-related, proteins.

A third potentially interesting protein identified is a WD-40 repeat-containing protein. Although the function of the protein is essentially unknown, ${ }^{56}$ WD-40 repeats are present in the C-terminal regulatory domain of Apaf-1. They were shown to be involved in self-association of Apaf-1 and regulation of caspase- 9 activation. ${ }^{57-59}$ WD-40 repeats are present in a variety of proteins with diverse functions and have been proposed to play a regulatory role. ${ }^{60}$

Also Arp2/3 complex subunit 4 (known as p20-Arc) was identified. The Arp2/3 protein complex is implicated in the control of actin polymerization. The complex consists of seven subunits including the actin-related proteins Arp2 and Arp3, and five others referred to as p41-Arc, p34-Arc, p21-Arc, p20-Arc and p16-Arc. ${ }^{61}$ Recent observations support a role for the Arp2/3 complex and/or actin polymerization in the movement of organelles in eukaryotic cells and yeast. ${ }^{62,63}$ Although the precise localization of the different components is unknown, Arp2/3 complex subunits colocalize with the mitochondria in intact yeast. ${ }^{63}$ Thus it is possible that the Arp2/3 complex subunit 4 identified here plays a role in cytoskeletal rearrangements and/or mitochondrial changes in the ultrastructural organization during the process of apoptosis. ${ }^{64}$

Finally, we also found the type-I RNA helicase Upf1 as being released under influence of tBid. Upf1 is involved in regulation of translation by operating in the nonsensemediated decay of mRNA. ${ }^{65,66}$ It is remarkable that our protein analysis revealed two large proteins, viz. 123-kDa type-I RNA helicase and $93-\mathrm{kDa}$ endoplasmin. In fact, the maximum protein size for mitochondrially released proteins is considered to be approximately $\sim 80 \mathrm{kDa} .{ }^{34}$ However, it is not clear if this release is associated with an action of tBid on the mitochondria, since Upf1 is associated with polyribosomes or resides in the cytosol, depending on its phosphorylation status. ${ }^{67}$ Endoplasmin (also called GRP94), a hsp90 member of glucose-regulated proteins, was described as a chaperone associated with the ER. ${ }^{68}$ Endoplasmin has been reported to have antiapoptotic properties and to be a proteolytic target for calpains during etoposide-induced apoptosis. ${ }^{69}$ Although a mitochondriaassociated localization of these two proteins cannot be excluded, their presence in the supernatant of tBid-treated mitochondria may reflect a contamination of the isolated mitochondria with the ER; this may also imply that tBid has targets other than mitochondria. In this respect, Bcl-2 was also shown to localize to the ER. ${ }^{70,71}$

As expected, most of the proteins identified have been reported to have a mitochondrial subcellular localization. Moreover, Western blotting revealed that the release of proteins is most probably confined to the intermembrane space, since AK2 (but not the soluble matrix protein AK3) was shown to be present in the supernatant of tBid-treated mitochondria. Although glutamate dehydrogenase and methylmalonate semialdehyde dehydrogenase are matrix proteins, part of the proteins may be localized in the intermembrane space of the mitochondria. The same might be true for endonuclease $G$, which plays a role in mitochondrial DNA replication ${ }^{36}$, favoring the idea of matrix localization. Alternatively, one cannot exclude the possibility that matrix proteins are released from the mitochondria under certain conditions.

Our in vitro study clearly shows that a proteome analysis by MALDI-MS and PSD is a powerful tool to study the release of mitochondrial proteins under conditions of apoptotic signaling. Besides known apoptogenic mitochondrial proteins, some new potentially apoptogenic proteins were identified. Further investigation into the involvement of these proteins in the apoptotic process will permit to understand the function of their mitochondrial release, also under other pathophysiological conditions in which mitochondrial dysfunction occurs, such as senescence.

\section{Materials and Methods}

\section{Isolation of murine liver mitochondria}

C57BL/6 wild-type and Bcl-2-transgenic mice (kindly provided by Dr. I Rodriguez, Laboratory of Vertebrate Neurobiology, The Rockefeller University, New York, NY, USA) ${ }^{29}$ were used at the age of 7-12 
weeks. Transgenic offspring were identified by PCR using Bcl-2specific primers. Livers of wild-type and $\mathrm{Bcl}$-2-transgenic mice were homogenized in homogenization buffer $\left(5 \mathrm{mM} \mathrm{KH}_{2} \mathrm{PO}_{4} \mathrm{pH} 7.4,0.3 \mathrm{M}\right.$ sucrose, $1 \mathrm{mM}$ EGTA, $5 \mathrm{mM}$ 3-(N-morpholino)propanesulfonic acid). Mitochondria were purified as described previously ${ }^{39,72}$ and resuspended in cell-free system buffer $(10 \mathrm{mM}$ HEPES- $\mathrm{NaOH}$ $\mathrm{pH} 7.4,220 \mathrm{mM}$ mannitol, $68 \mathrm{mM}$ sucrose, $2 \mathrm{mM} \mathrm{NaCl}, 2.5 \mathrm{mM}$ $\mathrm{KH}_{2} \mathrm{PO}_{4}, 0.5 \mathrm{mM}$ EGTA, $2 \mathrm{mM} \mathrm{MgCl} 2,5 \mathrm{mM}$ pyruvate, $0.1 \mathrm{mM}$ PMSF, and $1 \mathrm{mM}$ dithiothreitol), kept on ice and used within $1 \mathrm{~h}$ of preparation.

\section{Analysis of tBid-induced release of mitochondrial proteins}

Mitochondria equivalent to $40 \mu \mathrm{g}$ of liver protein were incubated at $37^{\circ} \mathrm{C}$ in $100 \mu \mathrm{l}$ cell-free system buffer for $20 \mathrm{~min}$ with a serial dilution of recombinant tBid. Supernatants were separated from mitochondria by centrifugation at $20000 \times g$ for $10 \mathrm{~min}$ at $4{ }^{\circ} \mathrm{C}$. $1 / 5$ of supernatant was subjected to $15 \%$ SDS-PAGE, followed by Western blotting. Antibodies used for Western blots were anti-cytochrome $c$ (clone 7H8.2C12; PharMingen, San Diego, CA, USA), anti-AK2 and anti-AK3 (kindly provided by Dr. T Noma, Department of Biochemistry, Yamaguchi University School of Medicine, Yamaguchi, Japan). Blots were visualized with the chemiluminescence NEN Renaissance method (Du Pont, Wilmington, DE, USA) after incubation of membranes with secondary antibodies coupled to horseradish peroxidase (Amersham Pharmacia Biotech, UK).

\section{Protein and peptide preparation procedure}

In order to identify released proteins by MS, a mitochondrial equivalent of one liver was prepared (corresponding to approximately $1 \mathrm{mg}$ protein) and incubated with $170 \mathrm{nM}$ purified tBid for $20 \mathrm{~min}$ at $37^{\circ} \mathrm{C}$ (500 ng tBid/200 $\mu$ l of mitochondria equivalent to $1000 \mu \mathrm{g}$ of liver protein). Supernatant was prepared by $20000 \times g$ centrifugation for $10 \mathrm{~min}$ at $4^{\circ} \mathrm{C}$ and submitted to $15 \%$ SDS-PAGE analysis. Coomassie brilliant blue-stained bands corresponding to tBid-induced mitochondrial protein release were excised and transferred to individually wrapped Eppendorf tubes. Corresponding gel slices of a parallel run lane of proteins spontaneously released or dissociated from unstimulated mitochondria were used as negative controls. Ge slices were digested using trypsin, as described previously. ${ }^{73}$ After digestion, supernatant containing tryptic peptides was removed from the gel pieces and acidified using $1 \mu$ formic acid. A small fraction $(10 \%)$ of this mixture was concentrated on Poros 50 R2 beads (Roche Molecular Biochemicals, Basel, Switzerland) and used for MALDI-MS peptide mass-fingerprint analysis as previously described. ${ }^{74}$ Since the excised gel bands contained multiple proteins, no unambiguous protein identification was possible by solely using the obtained tryptic peptide mass maps. Therefore the remainder of the peptide mixture was loaded on a $1 \times 50 \mathrm{~mm}$ Vydac C18-column (The Separations Group, Hesperia, CA, USA); peptides were separated by reverse phase-HPLC using an acetonitrile gradient. Eluting peptides were automatically collected in an aqueous solution containing a small number of Poros $50 \mathrm{R} 2$ beads. $^{73}$ These fractions were completely dried in a centrifugal vacuum concentrator and stored at $-20^{\circ} \mathrm{C}$ for further analysis by MALDI-MS.

\section{MALDI-MS protein identification}

All MALDI-MS experiments were performed on a Bruker Reflex III MALDI-TOF mass spectrometer (Bruker Daltonik, Bremen, Germany). The peptides present in each reverse phase-HPLC fraction were first scanned in reflectron mode; peptides that were clearly enriched as compared to the negative control sample were further selected for MALDI-PSD analysis. The peptide fragmentation spectra obtained were automatically used for protein identification in a nonredundant protein database using MASCOT algorithm (http://www.matrixscience.com).

\section{Acknowledgements}

Research was supported by the Interuniversitaire Attractiepolen IV/26, the Fonds voor Wetenschappelijk Onderzoek-Vlaanderen (grant 3G.0006.01), the Bijzonder Onderzoeksfonds, and an EC-RTD grant QLRT-1999-00739. M van Gurp is a fellow with the Vlaams Instituut voor de Bevordering van het Wetenschappelijk-technologisch Onderzoek in de Industrie. $\mathrm{K}$ Gevaert is a postdoctoral researcher with the Fonds voor Wetenschappelijk Onderzoek-Vlaanderen. The authors thank Dr. I Rodriguez and Dr. T Noma for providing anti-Bcl-2-transgenic mice and antibodies, respectively, A Meeus and W Burm for expert technical assistance, as well as $M$ Goessens and $L$ Puimège for animal care.

\section{References}

1. Cain K, Brown DG, Langlais C and Cohen GM (1999) Caspase activation involves the formation of the aposome, a large (approximately $700 \mathrm{kDa}$ ) caspase-activating complex. J. Biol. Chem. 274: 22686-22692

2. Cain K, Bratton SB, Langlais C, Walker G, Brown DG, Sun XM and Cohen GM (2000) Apaf-1 oligomerizes into biologically active approximately $700-\mathrm{kDa}$ and inactive approximately 1.4-MDa apoptosome complexes. J. Biol. Chem. 275: 6067-6070

3. Du C, Fang M, Li Y, Li L and Wang X (2000) Smac, a mitochondrial protein that promotes cytochrome c-dependent caspase activation by eliminating IAP inhibition. Cell 102: 33-42

4. Liu Z, Sun C, Olejniczak ET, Meadows RP, Betz SF, Oost T, Herrmann J, Wu JC and Fesik SW (2000) Structural basis for binding of Smac/DIABLO to the XIAP BIR3 domain. Nature 408: 1004-1008

5. Verhagen AM, Ekert PG, Pakusch M, Silke J, Connolly LM, Reid GE, Moritz RL, Simpson RJ and Vaux DL (2000) Identification of DIABLO, a mammalian protein that promotes apoptosis by binding to and antagonizing IAP proteins. Cell 102: $43-53$

6. Wu G, Chai J, Suber TL, Wu JW, Du C, Wang X and Shi Y (2000) Structural basis of IAP recognition by Smac/DIABLO. Nature 408: 1008-1012

7. Ekert PG, Silke J, Hawkins CJ, Verhagen AM and Vaux DL (2001) DIABLO promotes apoptosis by removing MIHA/XIAP from processed caspase 9. J. Cell Biol. 152: $483-490$

8. Srinivasula SM, Hegde R, Saleh A, Datta P, Shiozaki E, Chai J, Lee RA, Robbins PD, Fernandes-Alnemri T, Shi Y and Alnemri ES (2001) A conserved XIAPinteraction motif in caspase- 9 and $S m a c / D I A B L O$ regulates caspase activity and apoptosis. Nature 410: $112-116$

9. Fiers W, Beyaert R, Declercq W and Vandenabeele P (1999) More than one way to die: apoptosis, necrosis and reactive oxygen damage. Oncogene 18: 77197730

10. Vande Velde C, Cizeau J, Dubik D, Alimonti J, Brown T, Israels S, Hakem R and Greenberg AH (2000) BNIP3 and genetic control of necrosis-like cell death through the mitochondrial permeability transition pore. Mol. Cell. Biol. 20:54545468

11. Wang K, Yin XM, Chao DT, Milliman CL and Korsmeyer SJ (1996) BID: a novel BH3 domain-only death agonist. Genes Dev. 10: 2859-2869

12. $\mathrm{LiH}, \mathrm{ZhuH}, \mathrm{Xu}$ CJ and Yuan J (1998) Cleavage of BID by caspase 8 mediates the mitochondrial damage in the Fas pathway of apoptosis. Cell 94: 491-501

13. LuoX, Budihardjo I, Zou H, Slaughter CandWang X (1998) Bid, a Bcl2 interacting protein, mediates cytochrome $c$ release from mitochondria in response to activation of cell surface death receptors. Cell 94: 481-490

14. Heibein JA, Goping IS, Barry M, Pinkoski MJ, Shore GC, Green DR and Bleackley RC (2000) Granzyme B-mediated cytochrome c release is regulated by the Bcl-2 family members Bid and Bax. J. Exp. Med. 192: 1391-1402 
15. Barry M, Heibein JA, Pinkoski MJ, Lee SF, Moyer RW, Green DR and Bleackley RC (2000) Granzyme B short-circuits the need for caspase 8 activity during granule-mediated cytotoxic T-lymphocyte killing by directly cleaving Bid. Mol. Cell. Biol. 20: $3781-3794$

16. Sutton VR, Davis JE, Cancilla M, Johnstone RW, Ruefli AA, Sedelies K, Browne $\mathrm{KA}$ and Trapani JA (2000) Initiation of apoptosis by granzyme $B$ requires direct cleavage of bid, but not direct granzyme B-mediated caspase activation. J. Exp. Med. 192: $1403-1414$

17. Stoka V, Turk B, Schendel SL, Kim TH, Cirman T, Snipas SJ, Ellerby LM, Bredesen D, Freeze H, Abrahamson M, Bromme D, Krajewski S, Reed JC, Yin $\mathrm{XM}$, Turk V and Salvesen GS (2001) Lysosomal protease pathways to apoptosis. Cleavage of bid, not pro-caspases, is the most likely route. J. Biol. Chem. 276: 3149-3157

18. Krammer PH (2000) CD95's deadly mission in the immune system. Nature 407: 789-795

19. Wei MC, Lindsten T, Mootha VK, Weiler S, Gross A, Ashiya M, Thompson CB and Korsmeyer SJ (2000) tBID, a membrane-targeted death ligand, oligomerizes BAK to release cytochrome c. Genes Dev. 14: 2060-2071

20. Wei MC, Zong WX, Cheng EH, Lindsten T, Panoutsakopoulou V, Ross AJ, Roth KA, MacGregor GR, Thompson CB and Korsmeyer SJ (2001) Proapoptotic BAX and $B A K$ : a requisite gateway to mitochondrial dysfunction and death. Science 292: $727-730$

21. Lindsten T, Ross AJ, King A, Zong WX, Rathmell JC, Shiels HA, Ulrich E, Waymire KG, Mahar P, Frauwirth K, Chen Y, Wei M, Eng VM, Adelman DM, Simon MC, Ma A, Golden JA, Evan G, Korsmeyer SJ, MacGregor GR and Thompson CB (2000) The combined functions of proapoptotic Bcl-2 family members bak and bax are essential for normal development of multiple tissues. Mol. Cell 6: $1389-1399$

22. Eskes R, Desagher S, Antonsson B and Martinou JC (2000) Bid induces the oligomerization and insertion of Bax into the outer mitochondrial membrane. Mol. Cell. Biol. 20: 929-935

23. Yin XM, Wang K, Gross A, Zhao Y, Zinkel S, KlockeB, Roth KA and Korsmeyer SJ (1999) Bid-deficient mice are resistant to Fas-induced hepatocellular apoptosis. Nature 400: 886-891

24. Kluck RM, Bossy-Wetzel E, Green DR and Newmeyer DD (1997) The release of cytochrome c from mitochondria: a primary site for $\mathrm{Bcl}-2$ regulation of apoptosis. Science 275: 1132-1136

25. Gross A, Yin XM, Wang K, Wei MC, Jockel J, Milliman C, Erdjument-Bromage H, Tempst $P$ and Korsmeyer SJ (1999) Caspase cleaved BID targets mitochondria and is required for cytochrome $c$ release, while $B C L-X_{L}$ prevents this release but not tumor necrosis factor-R1/Fas death. J. Biol. Chem. 274: 1156-1163

26. Susin SA, Lorenzo HK, Zamzami N, Marzo I, Snow BE, Brothers GM, Mangion J, Jacotot E, Costantini P, Loeffler M, Larochette N, Goodlett DR, Aebersold R, Siderovski DP, Penninger JM and Kroemer G (1999) Molecular characterization of mitochondrial apoptosis-inducing factor. Nature 397: 441-446

27. Susin SA, Lorenzo HK, Zamzami N, Marzo I, Brenner C, Larochette N, Prevost MC, Alzari PM and Kroemer G (1999) Mitochondrial release of caspase-2 and -9 during the apoptotic process. J. Exp. Med. 189: 381-394

28. Krajewski S, Krajewska M, Ellerby LM, Welsh K, Xie Z, Deveraux QL, Salvesen GS, Bredesen DE, Rosenthal RE, Fiskum G and Reed JC (1999) Release of caspase-9 from mitochondria during neuronal apoptosis and cerebral ischemia. Proc. Natl. Acad. Sci. USA 96: 5752-5757

29. Rodriguez I, Matsuura K, Khatib K, Reed JC, Nagata S and Vassalli P (1996) A $\mathrm{bcl}-2$ transgene expressed in hepatocytes protects mice from fulminant liver destruction but not from rapid death induced by anti-Fas antibody injection. J. Exp. Med. 183: 1031-1036

30. Single B, Leist M and Nicotera P (1998) Simultaneous release of adenylate kinase and cytochrome $c$ in cell death. Cell Death Differ. 5: 1001-1003

31. Kohler C, Gahm A, Noma T, Nakazawa A, Orrenius S and Zhivotovsky B (1999) Release of adenylate kinase 2 from the mitochondrial intermembrane space during apoptosis. FEBS Lett. 447: 10-12

32. Nobumoto M, Yamada M, Song S, Inouye S and Nakazawa A (1998) Mechanism of mitochondrial import of adenylate kinase isozymes. J. Biochem. (Tokyo) 123: $128-135$

33. Denecker G, Vercammen D, Steemans M, Vanden Berghe T, Brouckaert G, Van Loo G, Zhivotovsky B, Fiers W, Grooten J, Declercq W and Vandenabeele P (2001) Death receptor-induced apoptotic and necrotic cell death: Differential role of caspases and mitochondria. Cell Death Differ. 8: 829-840
34. Patterson SD, Spahr CS, Daugas E, Susin SA, Irinopoulou T, Koehler C and Kroemer $G$ (2000) Mass spectrometric identification of proteins released from mitochondria undergoing permeability transition. Cell Death Differ. 7: 137-144

35. Prats E, Noel M, Letourneau J, Tiranti V, Vaque J, Debon R, Zeviani M, Cornudella L and Ruiz-Carrillo A (1997) Characterization and expression of the mouse endonuclease G gene. DNA Cell Biol. 16: 1111-1122

36. Cote $J$ and Ruiz-Carrillo A (1993) Primers for mitochondrial DNA replication generated by endonuclease $G$. Science 261: 765-769

37. Li LY, Luo X and Wang X (2001) Endonuclease $G$ is an apoptotic DNase when released from mitochondria. Nature 412: $95-99$

38. Parrish J, Li L, Klotz K, Ledwich D, Wang X and Xue D (2001) Mitochondrial endonuclease $G$ is important for apoptosis in C. elegans. Nature 412: 90-94

39. van Loo G, Schotte P, van Gurp M, Demol H, Hoorelbeke B, Gevaert K, Rodriguez I, Ruiz-Carrillo A, Vandekerckhove J, Declercq W, Beyaert R and Vandenabeele P (2001) Endonuclease G: a mitochondrial protein released in apoptosis and involved in caspase-independent DNA degradation. Cell Death Differ. 8: in press

40. Mirgorodskaya OA, Kozmin YP, Titov MI, Körner R, Sönksen CP and Roepstorff P (2000) Quantitation of peptides and proteins by matrix-assisted laser desorption/ionization mass spectrometry using ${ }^{18} \mathrm{O}$-labeled internal standards. Rapid Commun. Mass Spectrom. 14: 1226-1232

41. Munchbach M, Quadroni M, Miotto G and James P (2000) Quantitation and facilitated de novo sequencing of proteins by isotopic N-terminal labeling of peptides with a fragmentation-directing moiety. Anal. Chem. 72: 4047-4057

42. Susin SA, Zamzami N, Castedo M, Hirsch T, Marchetti P, Macho A, Daugas E, Geuskens M and Kroemer G (1996) Bcl-2 inhibits the mitochondrial release of an apoptogenic protease. J. Exp. Med. 184: 1331-1341

43. Marchetti P, Hirsch T, Zamzami N, Castedo M, Decaudin D, Susin SA, Masse B and Kroemer G (1996) Mitochondrial permeability transition triggers lymphocyte apoptosis. J. Immunol. 157: 4830-4836

44. Hirsch T, Decaudin D, Susin SA, Marchetti P, Larochette N, Resche-Rigon Mand Kroemer G (1998) PK11195, a ligand of the mitochondrial benzodiazepine receptor, facilitates the induction of apoptosis and reverses Bcl-2-mediated cytoprotection. Exp. Cell Res. 241: 426-434

45. Miccoli L, Poirson-BichatF, Sureau F, Bras Goncalves R, Bourgeois Y, Dutrillaux B, Poupon MF and Oudard S (1998) Potentiation of lonidamine and diazepam, two agents acting on mitochondria, in human glioblastoma treatment. J. Natl. Cancer Inst. 90: 1400-1406

46. Jin H, Kendall E, Freeman TC, Roberts RG and Vetrie DL (1999) The human family of Deafness/Dystonia peptide (DDP) related mitochondrial import proteins. Genomics 61: 259-267

47. Claros MG and Vincens P (1996) Computational method to predict mitochondrially imported proteins and their targeting sequences. Eur. J. Biochem. 241: 779-786

48. Gray CW, Ward RV, Karran E, Turconi S, Rowles A, Viglienghi D, Southan C, Barton A, Fantom KG, West A, Savopoulos J, Hassan NJ, Clinkenbeard H, Hanning C, Amegadzie B, Davis JB, Dingwall C, Livi GP and Creasy CL (2000) Characterization of human $\mathrm{HtrA2}$, a novel serine protease involved in the mammalian cellular stress response. Eur. J. Biochem. 267: 5699-5710

49. Faccio L, Fusco C, Chen A, Martinotti S, Bonventre JV and Zervos AS (2000) Characterization of a novel human serine protease that has extensive homology to bacterial heat shock endoprotease $\mathrm{Htr} A$ and is regulated by kidney ischemia. J. Biol. Chem. 275: 2581-2588

50. Leist $M$ and Jäättelä $M$ (2001) Four deaths and a funeral: from caspases to alternative mechanisms. Nat. Rev. Mol. Cell Biol. 2: 589-598

51. Valcarcel J and Gebauer F (1997) Post-transcriptional regulation: the dawn of PTB. Curr. Biol. 7: R705-R708

52. Cote J, Dupuis S and Wu JY (2001) Polypyrimidine track-binding protein binding downstream of caspase-2 alternative exon 9 represses its inclusion. J. Biol. Chem. 276: 8535-8543

53. Wang L, Miura M, Bergeron L, Zhu H and Yuan J (1994) Ich-1, an Ice/ced-3related gene, encodes both positive and negative regulators of programmed cell death. Cell 78: 739-750

54. Kumar S, Kinoshita M, Noda M, Copeland NG and Jenkins NA (1994) Induction of apoptosis by the mouse Nedd2 gene, which encodes a protein similar to the product of the Caenorhabditis elegans cell death gene ced-3 and the mammalian IL-1 $\beta$-converting enzyme. Genes Dev. 8: 1613-1626 
55. Kumar S, Kinoshita M, Dorstyn L and Noda M (1997) Origin, expression and possible functions of the two alternatively spliced forms of the mouse Nedd2 mRNA. Cell Death Differ. 4: 378-387

56. Muralikrishna T, Begum Z, Swamy CV and Khar A (1998) Molecular cloning and characterization of a tumor rejection antigen from rat histiocytoma, AK-5. DNA Cell Biol. 17: 603-612

57. Hu Y, Ding L, Spencer DM and Nunez G (1998) WD-40 repeat region regulates Apaf-1 self-association and procaspase-9 activation. J. Biol. Chem. 273: 33489-33494

58. Benedict MA, Hu Y, Inohara N and Nunez G (2000) Expression and functiona analysis of Apaf-1 isoforms. Extra Wd-40 repeat is required for cytochrome $c$ binding and regulated activation of procaspase-9. J. Biol. Chem. 275: 84618468

59. Adrain C, Slee EA, Harte MT and Martin SJ (1999) Regulation of apoptotic protease activating factor- 1 oligomerization and apoptosis by the WD-40 repeat region. J. Biol. Chem. 274: 20855-20860

60. Neer EJ, Schmidt CJ, Nambudripad R and Smith TF (1994) The ancient regulatory-protein family of WD-repeat proteins. Nature 371: 297-300

61. Welch MD, DePace AH, Verma S, Iwamatsu A and Mitchison TJ (1997) The human Arp2/3 complex is composed of evolutionarily conserved subunits and is localized to cellular regions of dynamic actin filament assembly. J. Cell Biol. 138 375-384

62. Boldogh IR, Yang HC, Nowakowski WD, Karmon SL, Hays LG, Yates III JR and Pon LA (2001) Arp2/3 complex and actin dynamics are required for actin-based mitochondrial motility in yeast. Proc. Natl. Acad. Sci. USA 98: 3162-3167

63. Boldogh IR, Yang HC and Pon LA (2001) Mitochondrial inheritance in budding yeast. Traffic 2: $368-374$

64. Skulachev VP (2001) Mitochondrial filaments and clusters as intracellular power-transmitting cables. Trends Biochem. Sci. 26: 23-29

65. Applequist SE, Selg M, Raman C and Jack HM (1997) Cloning and characterization of HUPF1, a human homolog of the Saccharomyces cerevisiae nonsense mRNA-reducing UPF1 protein. Nucleic Acids Res. 25: 814-82

66. Sun X, Perlick HA, Dietz HC and Maquat LE (1998) A mutated human homologue to yeast Upf1 protein has a dominant-negative effect on the decay of nonsensecontaining mRNAs in mammalian cells. Proc. Natl. Acad. Sci. USA 95: 1000910014
67. Pal M, Ishigaki Y, Nagy E and Maquat LE (2001) Evidence that phosphorylation of human Upf1 protein varies with intracellular location and is mediated by a wortmannin-sensitive and rapamycin-sensitive PI 3-kinase-related kinase signaling pathway. RNA 7:5-15

68. Takano S, Wadhwa R, Mitsui $Y$ and Kaul SC (2001) Identification and characterization of molecular interactions between glucose-regulated proteins (GRPs) mortalin/GRP75/peptide-binding protein 74 (PBP74) and GRP94. Biochem. J. 357: 393-398

69. Reddy RK, Lu J and Lee AS (1999) The endoplasmic reticulum chaperone glycoprotein GRP94 with $\mathrm{Ca}^{2+}$-binding and antiapoptotic properties is a novel proteolytic target of calpain during etoposide-induced apoptosis. J. Biol. Chem. 274: $28476-28483$

70. Krajewski S, TanakaS, Takayama S, Schibler MJ, Fenton W and Reed JC (1993) Investigation of the subcellular distribution of the bcl-2 oncoprotein: residence in the nuclear envelope, endoplasmic reticulum, and outer mitochondrial membranes. Cancer Res. 53: 4701-4714

71. Gross A, McDonnell JM and Korsmeyer SJ (1999) BCL-2 family members and the mitochondria in apoptosis. Genes Dev. 13: 1899-1911

72. Schotte P, Van Criekinge W, Van de Craen M, Van Loo G, Desmedt M, Grooten J, Cornelissen M, De Ridder L, Vandekerckhove J, Fiers W, Vandenabeele P and Beyaert R (1998) Cathepsin B-mediated activation of the proinflammatory caspase-11. Biochem. Biophys. Res. Commun. 251: 379-387

73. Gevaert K, Demol H, Sklyarova T, Vandekerckhove J and Houthaeve T (1998) A peptide concentration and purification method for protein characterization in the subpicomole range using matrix assisted laser desorption/ionization-postsource decay (MALDI-PSD) sequencing. Electrophoresis 19: 909-917

74. Gevaert K, Demol H, Puype M, Broekaert D, De Boeck S, Houthaeve T and Vandekerckhove J (1997) Peptides adsorbed on reverse-phase chromatographic beads as targets for femtomole sequencing by post-source decay matrix assisted laser desorption ionization-reflectron time of flight mass spectrometry (MALDI-RETOF-MS). Electrophoresis 18: 2950-2960 